\title{
K Masarykovským reminiscencím Karla Hrubého. Specifika Masarykova synergismu, kritika marxismu a strukturalistická demokracie Josefa Ludvíka Fischera
}

\author{
Jan Svoboda \\ Česká akademie věd, ČR
}

SVOBODA, J.: On Masarykian Reminiscences of Karel Hrubý: the Specifics of Masaryk's Synergism, the Critique of Marxism and the Structualist Democracy of Josef Ludvík Fischer

Philosophica Critica, vol. 7, 2021, no. 2, ISSN 1339-8970, pp. 17-40.

During the 1990s, Karel Hrubý reasonably reflected on the meaningfulness, but also on the philosophical and sociological impact of Masaryk's socially oriented legacy. Hrubý sees the qualitative continuity of our traditional ideological heritage, which is also a very important political heritage, mainly in the idea of so-called democratic socialism, which as a permanent task, after a historical confrontation with revolutionary Marxism-Leninism, programmatically set the Godesberg program in 1959. In the first step, the paper focuses on Masaryk's originally elaborated philosophy of humanism, on its social as well as metaphysical character, the functional essence of which Masaryk conceives as a theistically based synergism. Especially in the social context, which is always determined by a consistent effort for a close and effective connection between theory and practice, Masaryk's philosophy of humanity can generally be considered the ideological foundation of rational critique of the social conditions of the time, and therefore the cornerstone of Masaryk's critique of Karl Marx. After marking the fundamental ideological differences in the sociological concepts of Masaryk and Marx, the paper will in the next step focus on the concept of structuralist philosophy of Josef Ludvík Fischer, which in economic terms of its holistic composition can be considered as an original attempt to create a functional democracy with all attributes characteristic of the socialist system. At the end of the article, in substantial connection with Masaryk's and Fischer's thinking, Hrubý's own 
vision of the continuity of Czech history will be indicated, which is currently associated with some existential global humanitarian challenges. Their urgent solution in the 21st century cannot be achieved without the active participation and opinion plurality of individual nation-states and, therefore, requires a cultivated and intensively conducted intercultural dialogue.

Keywords: Critique of Marxism - Democratic socialism - Theistic synergism - Structuralist democracy - Intercultural dialogue Hrubý, K. - Masaryk, T. G. - Fischer, J. L.

„Chápu socialismus jako právě ten společenský životní styl, jenž umožňuje nejvyšší míru lidské svobody"

\section{Hrubého masarykovská výzva k demokratickému socialismu}

V průběhu devadesátých let minulého století se Karlu Hrubému podařilo na pozadí potřeb a možností politicky, ekonomicky i kulturně proměněné současnosti podat výstižnou rekonstrukci Masarykovy a Bernsteinovy kritiky marxismu a poukázat na nosné ideové průsečíky v jejich vlastních pojetích Hrubý (Hrubý 2019, 128-145). Sto let od prvního vydání Masarykovy České otázky se pak pro Karla Hrubého stalo výzvou k zamyšlení se nad její smysluplností i aktuálností a na pozadí analýz intenzity předcházejících totalitárních deformací také nad novými úkoly, na něž může svobodná demokratická společnost tradičně pozitivně navazovat (Hrubý 2019, 23-32). Jako vpravdě angažovaný intelektuál a především uvědomělý sociální demokrat, nezřídka kriticky polemizující s levicovějšími proudy v sociální demokracii, vyznačuje schůdnou cestu, kterou nikdy neopustil a o níž je celoživotně bytostně přesvědčen, že naplňuje reálnou míru humanity, tolerance a smyslu pro solidaritu. Směřování k tzv. demokratickému socialismu pro Hrubého povýtce znamená principiální možnost účinně, ale i tradičně (Zouhar 2013) navazovat v těchto nových společenských podmínkách na myšlenky Godesberského programu, jehož přijetím v roce 1959 došlo - po historické konfrontaci s revolučním marxismem-leninismem - k obratu k revizionismu a reformismu prakticky ve všech tradičních sociálnědemokratických a socialistických stranách (Hrubý 2019, 143; Hrubý 2005, 8-9).

\section{Masaryk a Bernstein}

Podobně jako Bernstein, také Masaryk ve své práci $O$ bolševictví - která vyšla nikoli náhodně právě v inkriminovaném roce 1921 (Masaryk

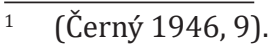


1990) - odmítá ruské metody. Masaryk připomíná, že naše situace i tradice jsou jiné, že dělnictvo u nás má silnou stranu zastoupenu ve vládě a v parlamentě: že cestou není revoluce, ale parlamentární demokracie (Hrubý 2019, 141-142). Společnost nicméně nelze emancipovat jen jakýmsi okleštěným a vágním politikařením či podbízivým populismem, které na pozadí často nedůstojných politických praktik postrádají potřebnou pozitivní společenskou vizi a stávají se tak pouhým přívěskem demonstrace svobody občanské a politické. Funkční demokratická pluralita v sobě musí nutně implikovat také otázky sociální - potřeby a možnosti těch, jež se na neúprosném kolbišti utváření světových dějin teprve společensky uvědomují - bud' jako třída, užší občanská skupina či politická nebo i „nepolitická" iniciativa. Toho si byli jak Bernstein, tak Masaryk dobře vědomi. Jejich odhodlaný a odpovědný osobitý př́istup, jenž byl umocňován téměř hmatatelnou emancipační energií tehdejší doby, přetavoval onen capitalis, ono „život ohrožující a formoval jej do podoby odcizenému člověku tvárnější, sympatičtější a nadějnější - navracel člověku lidskou tvář, jeho ztracenou důstojnost. Vyjádřeno slovy Karla Hrubého: „Socialismus jim není teoreticky zkonstruovaným cílem, nýbrž formou vývoje společnosti směřující k větší svobodě, spravedlnosti, vyšší životní úrovni, vyšší kultuře a také k větší sociální odpovědnosti a vzájemné solidaritě" (Hrubý 2019, 143).

Socialismus pro Bernsteina i Masaryka tedy představuje „trvalý úkol“, náročné a nekončí úsilí „vybudovat svobodu a spravedlnost, chránit ji a chránit sebe v ní," a tudíž nelze tento pojem jednostranně vnímat jen s souřadnicích určitého hospodářsko-společenského systému (Šamalík 2006, 28-29). Je postojem svobodného a odpovědného člověka, který plnohodnotně pochopil vysoce inspirativní význam Bernsteinovy teze: hnutí je vším, cíl ničím, a to včetně jejího soupatřičného morálního apelu a zdůvodnění. Jenom $v$ souladu s touto neopomenutelnou etickou dimenzí, v níž ono masarykovské „Vždy a všude odporovat zlému“ nalézá nutný pozitivní antipod, se pak socialismus teprve může stát „účinnou hradbou proti sociální křivdě a snižování lidské důstojnosti proti všem - i proti marxistické teorii“ (Hrubý 2019, 129)!

Masaryk však - na rozdíl od angažovaného socialisty Bernsteina přistupoval ke kritice marxismu s originálně vypracovanou filosofií humanismu. Právě její transcendentně ukotvená eticko-náboženská rovina, kterou Masaryk považoval za nejvlastnější dimenzi existenciální, nám teprve nabízí kýžené ideové východisko všech jeho sociálně orientovaných demokratizačních snah, at' už postupných, tak i těch revolučně-reformních (Masaryk 1996, 410), jež svou nečekanou intenzitou následně vyvstaly jako podložené a oprávněné obavy s rozbřesky první světové války. 
Masarykův eticky pojatý socialismus, který odmítá každý materialistický fatalismus, stojí na zcela odlišné pozici, než je založen evoluční socialismus Bernsteinův. Masarykův filosofický postoj do sebe pozoruhodně integruje a v duchu koncepce „vědecké“ metafyziky (Masaryk 2001) neméně racionalisticky rozvíjí Masarykovu neutuchající modernistickou víru v teistický determinismus, jenž je - jako onen bazální sociální nexus - vlastní dynamickou podstatou jeho pojetí sociální soudržnosti a v další nutné sociologické konsekvenci i možného progresu společnosti vůbec. Jak se ostatně Masaryk vyslovil v Otázce sociální: „Sám si vykládám svět a historii teisticky: teistický determinismus je mně pak synergismem nejen sociálním, ale právě i metafyzickým“ (Masaryk 2000b, 209).

S podobným racionálně melioristickým akcentem - leč nábožensky indiferentněji - pojímá Masarykovu filosofii humanismu a demokracie také Karel Hrubý. Chápe ji jako „eticky pojatý osobní a sociální synergismus“ (Hrubý 2019, 143). Pokusme si tedy nejprve stručně položit otázku: V čem spočívá ona tvůrčí podstata Masarykova specifického pojetí teisticky založeného synergismu? Náhled do tohoto filosofického principu by nám měl poskytnout potřebnou ideovou bázi, která je hledaným filosofickým východiskem Masarykovy kritiky Marxe a marxismu vůbec. V dalším kroku pak přejdeme ke koncepci strukturalistické filosofie Josefa Ludvíka Fischera, kterou lze v ekonomickém ohledu její celostní skladby považovat za originální pokus o vytvoření funkční demokracie se všemi atributy charakteristickými pro socialistický systém. Pro potřeby naznačení vývojové kontinuity českého myšlení se stejně tak stručně dotkneme možných ideových návazností, které Fischera s Masarykem tradičně sbližovaly, a tedy i otázky, do jaké míry tyto potenciální vztahové veličiny mohly v zásadě myšlenkově ovlivnit povahu Fischerovy kriticky směřované filosofie.

\section{Masarykův synergismus: mezi vědou a vírou}

Je třeba nejprve předeslat, že Masaryk tuto povýtce teisticko-racionalisticky směřovanou otázku dlouhodobě principiálně promýšlel a soustavně filosoficky rozvíjel. $V$ počátcích své myslitelské dráhy měl potřebu se vyrovnat s pozitivismem. Ten ho na jedné straně přitahoval pro jeho vědeckou exaktnost, pro důraz na objektivní fakta a pro jeho odmítání všech idealistických substrukcí a vzletů. Na straně druhé však Masaryk věděl, že pozitivismus svým jednostranným objektivním přístupem přehlíží celou oblast našeho subjektivního prožívání. Od této existenciálně zakotvené sféry nelze odhlížet, jak to činí pozitivismus. Nemáme podle Masaryka jen vědomí o objektivní realitě. Jako svobodní a mravně odpovědní jednotlivci prožíváme skutečnost, která je naší přirozenosti nejvlastnější, jeho slovy: 
„Máme nejen vědomí, ale i svědomí“ (Masaryk 2012, 11-12 a 254). Kam až podle Masaryka sahá omezená pravomoc pozitivistického př́stupu, vystihuje $v$ dalších upřesňujících filosoficko-sociologických souvislostech věta, jíž si na samém prahu nového století na vrub pozitivismu kriticky poznamenává: „Je chyba positivismu, že pro samou historii a samé počítání s fakty a dokumenty zapomíná na svědomí, jako by to nebylo faktem, nebylo stejně positivním. A to stálé předvídání toho, co ,se' stane - nestane ,se' pouze, ale já to musím udělat, já se musím rozhodnout svou vưlí a svým svědomím“ (Masaryk 1946, 49).

Na pozadí těchto skutečností se stává postupně zřejmé, že Masarykovo myslitelské úsilí je předznamenáno jakýmsi specifickým napětím mezi „vědou“ - její objektivitou, ale i její otevřeností pro stále nové hypotézy: její „falibilitou“ a „vírou“ - jistotou našeho svědomí (Svoboda 2018, 686-694).

Už v sedmdesátých letech 19. století si Masaryk uvědomoval, že moderní evropský a racionálně uvažující člověk se nachází v hluboké existenciální krizi. Typickým projevem této krize je přemíra sebevražednosti (Masaryk 1998, 197-201). Pod tlakem pokroku vědy a její objektivistické metody nelze nekriticky věřit ve středověká církevní dogmata a tradice. Masaryk nicméně stejně tak dobře věděl, že tento kriticky uvažující moderní člověk citové ukotvení potřebuje. Na jedné straně je tedy novodobý člověk poznamenán skepsí a agnosticismem, které všechny subjektivní poznatky a metafyzické substrukce považují za nejisté; tento novodobý skeptický postoj tehdy Masarykovi ztělesňoval David Hume (Masaryk 1998, 11-61). Na straně druhé to byl Blaise Pascal, exaktní vědec, který svým celoživotním úsilím stejně tak vroucně hledal nejosobnější vztah k Bohu (Masaryk 1998, 65-95). Masaryk autenticky postihl Pascalovu fatální rozpolcenost mezi „vědou“ a „vírou“. Rozpoznal, že Pascal nevolal po důkazech boží existence. Pascal prahnul po nejosobnějším prožívání skutečnosti boží přítomnosti - po „skoku“ víry, v němž viděl nejvnitřnější vyjádření touhy moderního člověka po citové translaci k boží transcendenci. Právě těmito dvěma klíčovými přednáškami se Masaryk uvedl jako čerstvě jmenovaný profesor filosofie na nově vzniklé české větvi KarloFerdinandovy university v Praze.

Poté Masaryk přistoupil k vypracování koncepce tř́ídění a systému věd v knize Základové konkretné logiky (Masaryk 2001b). V podstatě se přidržoval tradičního pojetí, které vypracoval pozitivista a sociolog Auguste Comte. Přesto ale - po vzoru Johna Stuarta Milla i Masarykova vídeňského učitele Franze Brentana - sociologii (kterou v podstatě Masaryk redukoval na sociální dynamiku, tj. na filosofii dějin) do obecné stupnice věd zařadil po psychologii jako její organickou součást (Masaryk 2001a, 34): psychologie je podle Masaryka vědou „základní“; vědomí Masaryk považuje 
za jev „sui generis“ a je nám, podle jeho slov, „o sobě zajištěno“, čili, jak dále Masaryk vyvozuje, psychologie jako „jediná“ věda propůjčuje člověku „absolutní poznání“ (Masaryk 2001a, 101-115). Právě psychologii Comte odmítal považovat za objektivní vědu, nebot' ji vnímal jako součást biologie, resp. fyziologie. To má svou důležitost pro porozumění jedinečnosti Masarykovy klasifikace věd.

Ono zesubjektivizování takto Masarykem předloženého obecného systému věd má podstatné důsledky pro jeho pojetí psychologie. Z hlediska funkčnosti celé koncepce vědecké filosofie Masaryk nepojímá psychologii jako samostatnou vědní disciplínu. Jakožto výchozí věda Masarykova vědeckého systému má také svou nedílnou metafyzickou dimenzi, a ta pak určuje ráz jeho pojetí etiky a potažmo i náboženství (Masaryk 2012, 312-326). Tím vyniká další rys Masarykovy filosofické koncepce, který upřednostňuje uvědomělé mravní rozhodování a jednání. Je příznačné, že na počátku století Masaryk etiku považuje za „jádro“ filosofie (Masaryk 1900, 12; Masaryk 1902, 2).

$\mathrm{Z}$ výše naznačeného Masarykova noetického přístupu v podstatě vyplývají dvě principiální konsekvence. $V$ prvé řadě jde o to, že od samých svých myslitelských počátků Masaryk vnímal skutečnost jako úzké propojení teorie a praxe. Stejně tak se stalo zřejmé, že objektivní skutečnost jako celek, tj. nejen příroda, ale i kulturně-politická a sociální, ekonomická či environmentální oblast, je srozumitelná jen v pozitivním vědecko-kritickém vztahu k člověku - člověku jako angažovaném jednotlivci, který je principiálně ukotveným mravním subjektem.

Tato obecně platná filosofická východiska lze pak považovat za vlastní fundament Masarykova pojetí demokracie. Nicméně ne bezvýhradně. Tato fundamentální zjištění nabývají svůj konkrétní sociologický význam jen tehdy, pokud naleznou své ideové oprávnění v pozitivním smyslu moderních dějin, jichž je každý národ neodmyslitelnou součástí. Za onu pozitivní ideu, která je vlastním smyslem či ideálem moderních dějin a jejich pozitivního směřování, Masaryk považuje ideu humanity (Masaryk 2000a, 148-159).

Masaryk věřil, že každý jednotlivý národ naplňuje tento univerzální ideál svým vlastním způsobem. „Angličané jej formulovali hlavně eticky, Francouzové politicky (prohlášením práv člověka a občana), Němci sociálně (socialismus), my národnostně a nábožensky“ (Masaryk 2005, 391M; Masaryk 2000c, 149). Sám pak - s odvoláním na své novodobé ideové předchůdce - nachází tuto univerzální ideu v reformním náboženském úsilí Jana Husa a v následné - téměř 200 let trvající - české reformaci.

Masarykovo pojetí smyslu českých dějin tedy vycházelo ze svobodomyslné tradice husitství - $\mathrm{z}$ onoho „zletilého“ důrazu české reformace 
na humanitu a svědomí jednotlivce. $V$ tomto pozdně středověkém období však ještě nešlo o formování českého národa v moderním smyslu. Šlo spíše o jakýsi pokus o vytvoření specifického prostředí náboženské plurality, která se měla stát budoucím ideovým předpokladem kulturní a politické demokratické společnosti. To si Masaryk dobře uvědomoval. Proto právě náboženskou spiritualitu Masaryk považoval za vlastní integrální složku této naší specificky české reformační tradice. Demokracie potom Masarykovi v důsledku znamenala doslova „soustavně“ a opravdově praktikovanou zbožnost - humanita a demokracie jsou mu otázkou „svědomí“, jak často připomínal.

V náboženské spiritualitě tedy hledal potřebný tmel, který životu, potažmo pak i politice propůjčuje onu neodmyslitelnou mravní integritu a konzistenci. Je však třeba zmínit, že Masarykova nekonvenční víra v potřebu spirituality vyústila na prahu první světové války v tzv. antropismus či antropologismus (Masaryk 1995, 152-155; Svoboda 2018, 693). Tento specifický antropologický obrat je pak možné chápat jako nutnou předjímku nové epochy lidství - čili i nové epochy principiálních postojů člověka-občana. V této době Masaryk nevratně odmítá starou disfunkční monarchistickou vládu aristokracie a teokracie a na její místo staví demokracii: demokracii jako „víru v člověka“, která bude uskutečňovat, doslovně, „boží řád na zemi“ (Čapek 2013, 208-211), především pak moderní ráz nové Evropy (Masaryk 2016). V duchu radikální české reformace požaduje celkovou kvalitativní proměnu společnosti - jak demonstrativně prohlašuje: požaduje „revoluci hlav a srdcí“.

Masaryk ani v této pozdější fázi myšlenkového vývoje nepochyboval, že náboženství je „centrální a centralizující mocí“ v životě člověka i společnosti“ (Masaryk 1996, 425). Nicméně u něho sílí kritika dogmat, politického katolicismu a opouští původní ideu federativního ústavního uskupení Čechů v rámci Rakousko-Uherské monarchie - myšlenku tzv. „austroslavismu“. Masarykova kritika se však nevyčerpává povšechným antikatolicismem. Jeho kritika si bere pod drobnohled všechny formy „vnějšího“ církevního náboženství (Šolcová 2017, 537-551). Smyslem Masarykových náboženských snah také není pouhé smíření vědy s náboženstvím, ale vytvoření zcela nového náboženského a duchovního obsahu života, který je v souladu s kritickým rozumem (Masaryk 1996, 426).

Za základní dynamickou komponentu této novodobé demokratické spirituality Masaryk považuje hledisko věčnosti. Není však hlediskem nedostupného transcendentna, odsunutého do vzdálené budoucnosti. Smysluplně se zpřítomňuje jen v neodlučitelné funkční korelaci se světem našeho života, který se v Masarykově realistickém pohledu účelově ztělesňuje v nesčetném množství forem a právě jimi je původně také in concreto 
determinován (Čapek 2013, 158-161). Na tomto působivém utváření sub specie aeternitatis se podle něho přirozeně podílí i člověk a ve své zvláštní vývojové pozici se tak stává trvalým partnerem Boha v procesu této tvořivosti. Pojmy „Prozřetelnost“ nebo „věčnost“ je proto třeba u Masaryka chápat „nikoli jako objektivisticky chápané entity, ale jako hledisko, vztahování k vyššímu celku s předpokládanou jeho řádovostí", konstatuje Lubomír Nový (Nový 1994, 105). Možnost se trvale kvalitativně vztahovat $\mathrm{k}$ transcendenci této nadčasové (a strukturálně vrstvené) řádovosti pak propůjčuje pojmu věčnost kýženou dynamiku „zde a nyní“, v níž Masaryk jako modernista neochvějně věří, a stává se jako onen zpřítomňující funkční horizont tvůrčí vertikálou života prostupující naše každodenní jednání, nebot' se uplatňuje v konkrétní mravní odpovědnosti za sebe i ostatní. Masarykův důraz na potřebu lidského aktivismu, jenž je principiálním důsledkem jeho osobitého ("metafyzicky“ podloženého) teistického pojetí, tudíž spočívá v soustředění se na tzv. „drobnou práci“ jako reálného východiska pro vytváření humanity v rámci demokracie jakožto její možné a osvědčené sociální formy.

\section{Masarykova kritika Karla Marxe}

Právě v tomto nadčasovém a dialogicko-kritickém emancipačním duchu pak základní Marxovy teze Masaryk poměřuje relevantní nábožensky motivovanou filosofií humanity. $V$ podstatě nejsilnější výtkou proti marxismu z Masarykovy strany tehdy bylo, že v procesu poznávání nedoceňuje aktivní roli subjektu (Grim Feinberg 2019, 144-156). Tato zásadní výtka souvisí $\mathrm{s}$ Masarykovou vírou či reflektovaným přesvědčením $\mathrm{v}$ jakousi, řekněme, procesuální teleologii lidství, v onu působivou „cílesměrnost" světa a života, jež dovoluje poznávajícímu subjektu účelově pronikat k samému smyslu i hodnotě jednotlivých věcí a tím skutečnost takříkajíc „oduchovňovat“. Každé „smysluplné“ vyhodnocování, tj. vědomé uznání užitečnosti a vhodnosti jednotlivin vždy v podstatě předpokládá reflektivní výkon určitého subjektu - jeho, jak Masaryk (v brentanovských intencích) ř́ká, „uznávající úsudek“, a tudíž nejde jen o jakýsi „odosobněný“ hodnotící akt. Masaryk nepopírá, že „práce sama o sobě přeměňuje př́rodniny a věci vůbec“. Nicméně „sama hodnoty neurčuje“. Hodnota zboží je podle něho v podstatě vytvářena živou poptávkou na trhu práce a je tedy vždy primární otázkou, „zda-li bude ta přeměna někým a kdy uznána jako užitečná a vhodná, bude-li se komu líbit“. Proto Marxovo „učení, že „pouze práce tvoří hodnotu“, Masaryk považuje za objektivně „očividně“ nesprávné (Masaryk 2000b, 233-234). Nelze podle Masaryka odhlížet od skutečnosti, že „i v práci je prvek subjektivní: energie a její intenzita, nakonec tedy zase - vůle, a když vůle, tedy také motivy“ (Masaryk 2000b, 236). 
Masaryk zdůrazňuje, že Marx se kategorii užitku a hodnotícím soudům „vyhýbá". Užitečnost jako kategorii ekonomickou Masaryk považuje v samé své podstatě za kategorii subjektivní a etickou, nebot' „užitečné“ primárně odvozuje z našich potřeb, přání a chtění, tedy ze skutečnosti, o níž více či méně vědomě usilujeme. A pokud se nábožensky opodstatněná etika postupně stává kvintesencí filosofie a je ve smyslu i oněch nejvyšších praktických výkonů vlastním noetickým fundamentem psychologie, ve svém neodmyslitelném vědecko-metafyzickém důsledku to znamená, že společenskou rovnost občanů Masaryk obecně chápe jako rovnost primárně nábožensko-duchovní a teprve z této prapůvodní nadčasové roviny bezprostředně vyvěrá ono krédo rovnosti mravně uvědomělých a tudíž svobodných lidských duší.

$\mathrm{V}$ tom tkví kořen Masarykova univerzalismu a současně vlastně odpověd' na to, proč v principu odmítá přijmout každou dílčí, tedy „časnou“ ideologii, která do popředí své koncepce staví kolektivní vědomí a neklade potřebný důraz na vědomí i svědomí jednotlivce, at’ už se jedná o víru v pokrok tehdy inspirovaný tradiční pozitivismus nebo následně marxismus. Právě ono záměrné „zesubjektivizování“ celého Masarykova vědeckého systému psychologií, jež pak nutně podmiňuje i jeho pojetí specifičnosti národních povah, je důvodem, proč svůj transcendentně ukotvený apel subjektivní odpovědnosti takříkajíc, Komenského slovy - „k nápravě věcí lidských" považuje v duchu svého realistického důrazu na „drobnou“ práci za lék proti každému druhu objektivisticky směřovaného „utopismu“ (Comtův finalismus nevyjímaje).

Nezůstává však u pouhého zobecňujícího konstatování, že „práce skutečná [...] je práce malá, drobná, všední" (Masaryk 2000c, 197). Jeho účelově a vědecky „věcně“ orientovaný aktivismus má ve skutečnosti pronikat každou oblastí konkrétní lidské činnosti - včetně právě „moderní“ etiky. Masaryk proto odmítal všechny skokové „heroické“ změny, tj. i každou fantastiku revoluce. Skutečnost vnímal v širších historických souvislostech, jež jsou vždy podmíněny (infinitezimální) otevřeností pro naplňování př́íslušných tvůrčích potencialit. I navzdory doprovodným a důvodně emergujícím fázím tzv. dějinného „odkroku“ Masaryk upřednostňoval především svůj racionálně a důsledně vedený smysl pro vývojovou kontinuitu $\mathrm{s}$ oním potřebným pozitivistickým důrazem na vědy a vědeckou metodu, čímž se stavěl do vědomé opozice vůči německému klasickému idealismu. Jeho slovy: „Tak jako věda pravá zabývá se jevy nejvšednějšími, tak pracovníkem skutečným je ten, kdo dovede dělat práce malé, všední, nutné, a kdo je dělat chce. Co je matematice infinitezimální počet, co jsou psychologii a fyziologii malé, téměř nevnímatelné prvky počitkové, co jsou přírodovědě atomy a mikroby, to je moderní etice práce drobná. Drobná práce 
je opravdu praktická, skutečná práce životní - takzvané veliké činy, činy heroické, také hrdinství revoluce jsou větší ve fantazii než ve skutečnosti. Utopismus se překonává drobnou prací. Prací se také překonává revolucionismus" (Masaryk 2000c, 197).

V této jeho jakési aktivisticko-kritické a soustavně vedené metodě postupného a rozvážného odkrývání konkrétního problému „pod úhlem věčnosti“ je pak obsaženo i Masarykovo existenciálně založené pojetí víry v lidskou práci. Vychází-li totiž ona duchovně ukotvená víra v ideál humanity z křestansky upřímné a nesobecké lásky k bližnímu jakožto principiální normativní sankce, je také právě nábožensko-duchovní rovina oním původním nadčasovým zdrojem smyslu i hodnoty Masarykova pojetí neutuchající „drobné“ lidské práce, ale i potřebné tvůrčí sociální motivace směřované k našim bližním. Masarykovi jde o jakési nadčasově ukotvené uchopení smyslu a hodnoty lidské práce, o jakýsi „životní“ postoj spočívající ve svobodném, ale i trvalém převzetí odpovědnosti každého jednotlivce za tento povýtce lidský tvůrčí fenomén.

Stává se postupně zřejmé, že Marxovu úzce sociologicky pojatou „monokauzální" metodu, resp. jeho teorii základny a nadstavby, která vykládá svět člověka čistě jako „reflex“ či „ukazatel“ jeho ekonomických podmínek (Masaryk 2000b, 131), Masaryk považuje ze svého specifického myšlenkového pohledu za noeticky, ale i psychologicky nedostačující. Např. právě náboženskou reformaci, ale vlastně vývoj náboženství obecně nelze takto „př́močaře“ redukovat, slovy Masarykovými - na „historii kšeftovní" (Masaryk 2000b, 137). V důsledku to podle Masaryka znamená, že „Marxova redukce všech sil sociálních a historických na hospodaření, ekonomický materialismus, vede k prohlášení individuálního vědomí za iluzi“ (Masaryk 2000b, 140). A pokládá si vpravdě existenciálně laděnou otázku: „Můžeme vyložit osobní vztah člověka k Bohu a k světu, vztah promyšlený a procítěný, jako ,masku’ poměrů hospodářských“ (Masaryk 2000b, 134)?

Člověk podle Masaryka nezaznamenává, a následkem toho nepopisuje jen skutečnost, která se mu jeví jako něco, co se rozprostírá jaksi „naivně“ před ním. „Člověk jako bytost, která si sebe sama uvědomuje, pocit’uje svou osobnost a svou hodnotu vůči světu“ (Masaryk 2001a,174) - a to zcela realisticky. Následující věta je toho dokladem, když právě v souvislosti s kritikou Karla Marxe Masaryk prohlašuje: „Minerál není faktem o nic více ani faktem bezpečnějším než to, že nás nelidskost trápí a lidskost těší“ a „svědomí je tak dobře daný fakt jako jiné fakty a zjevy“ (Masaryk 2000c, 144). Masaryk tedy zdůrazňuje, že pro naše hodnocení vnějších poměrů máme důvody vnitřní a že „nebýt v zárodku citů pravé lidskosti, nebylo by lidstvo nikdy dosáhlo toho mravního stupně, na němž dnes je, a nevypracovalo by se tam, kam dnes spěje“ (Masaryk 2000c, 145). Realita těchto „důvodů 
vnitřních, vážených z vlastní duše" (Masaryk 2000c, 144), ale není o nic méně reálnější (pozitivnější) než realita důvodů vnějších.

Masaryk nechce znát pouhá (vnější) surová či „brutální“ fakta (Masaryk 2012, 255, 329, 348), jimiž britští empirici označovali data bezprostředního vědomí. Chce „také vidět, jaký mají smysl, k čemu ukazují“ (Čapek 2013, 39). Říká: „Smysl vývoje světového nelze ovšem postihnout tím pustým historizujícím, vlastně chronologickým empiricismem, jemuž značná část historiků hoví, nýbrž posuzováním a srovnáváním filosofickým právě hledáním smyslu ve spoustě faktů" (Masaryk 1900, 910; Masaryk 2000b, 128). Proti „upř́lišněnému“ historismu - ale i mytologii (Funda 2002, 623) - staví „interpretativní“ realismus (Nový 1994): napřed věci (pro nás), - „moment světa statický a nikoli dynamický zdá se mi vlastním a hlavním cílem našeho myšlení", konstatuje Masaryk (Masaryk 2000b, 80; Svoboda 2019, 101-104). Zaměřuje se tedy především na „smysluplné" dosahování sociálního konsensu participujících jedinců nebo jejich dílčích uskupení, nikoli na jednostrannou reflexi minulosti a už vůbec ne na náhlý revoluční zvrat. Navíc třídní boj, jenž podle Marxe v revoluci nutně vyúst'uje, podle Masaryka neodpovídá skutečným historickým, kulturním, náboženským, ale ani reálně politickým „snahám a tužbám“ jednotlivých národů: upřednostňuje tedy potřebu dlouhodobějších reformních procesů před náhlou revoluční změnou. $\mathrm{V}$ tom se podobal Bernsteinovi a na sklonku života i Engelsovi (Hrubý 2019, 133; Masaryk 2000b, 253).

Je třeba nicméně dodat, že ačkoliv Masaryk vycházel z předpokladu, že země zasažené protestantismem inklinují k revolučním zvratům menší měrou, současně nezapomínal, že právě americká deklarace nezávislosti pokládá revoluci za „právo přirozené“. Také zde lze spatřovat jisté myšlenkové konotace s jeho pozdějším pojetím Světové revoluce (Lochman 1998, 431). Tím však Masarykův smysl pro sociální reformismus nepozbývá trvalé platnosti. Novodobé a historicky potvrzené přesvědčení $v$ epochální vítězství demokracie pro něho vždy bylo (i v jeho pozdějším tvůrčím období) neodmyslitelně spjato s myšlenkou státní a politické nezávislosti a Masaryk nikdy nezpochybňoval fakt, že ji bude možné prakticky uskutečňovat jen v nutném souladu s prosazováním lidských práv - s potřebným striktním důrazem na jejich neodmyslitelný humanitně zaměřený ideový náboj předcházející každou zákonodárnou kodifikaci, onen důraz, jenž Marx, ani Engels podle Masaryka „nedocenili“ (Masaryk 2000c, 149; Hrubý 2019, 27-28). Právě onen zvláštní akcent na potřebu lidských práv, na jejich principiální uchopení i v širších sociálních, potažmo pak také ekonomických i kulturních kontextech, olamuje hrot možného nařčení Masarykovy koncepce z jakési prvoplánové naivity či moralistického 
sentimentalismu a řadí Masaryka k předním průkopníkům lidských práv především $\mathrm{v}$ této sociální oblasti.

Je však třeba v těchto souvislostech neopomenout, že Masarykova kritika je kritikou konce devadesátých let 19. století. Neopírala se o některé Marxovy rané práce jako např. Ekonomicko-filosofické rukopisy (Paříž, 1844) či Grundrisse (Londýn, 1857-58), které vyšly dlouho po vydání Masarykovy Otázky sociální. Stejně tak výběr sekundární literatury byl v porovnání s dneškem značně omezený a v mnoha podstatných ohledech a ideových finesách nerozpracovaný (Masaryk 2000b, 20-32). Masaryk si však vysoce cení Marxova tvůrčího obratu k otázce sociální, oceňuje potřebnou pozitivní pozornost, jíž věnoval vlivu ekonomických podmínek na utváření lidského života a přitom neopomenul zdůraznit protihumanistický ráz a nedůstojnost lidské bídy, což vlastně odpovídá Marxově úsilí o propojení teorie s praxí. $\mathrm{V}$ tomto ohledu považuje marxismus (resp. „socialismus“) za jeden z naléhavých „ideálů humanitních“ současnosti (Masaryk 1946, 11-20).

Odmítá však názor, že etika vyvěrá jen a pouze z možností a potřeb určité třídy lidí. Takovou etiku, at' už ji nazýváme buržoazní nebo proletářskou, Masaryk chápe jako, jak ř́ká, „amoralismus“ (Masaryk 2000b, 112); je vždy pro něho etikou nedostatečně principiálně odůvodněnou a tedy nedůslednou, nebot' se ve smyslu marxismu ideologicky odvozuje právě jen z materiálních potřeb uvědomujícího se průmyslového proletariátu. Emancipační úsilí tzv. čtvrtého stavu, které Masaryk vnímal jako jednu z dobových snah spojených s další nutnou humanizací společnosti, chtěl řešit reformně, nikoli náhlým sociálním zvratem - revolučně. Masaryk v podstatě upřednostňoval jakousi celostní důmyslnou snahu o prohlubování odbornosti a kompetentnosti založenou na vědeckém př́ístupu a vědeckosti vůbec, jejímž cílem bylo navazovat na vše historicky pozitivní, a to tedy včetně pozitivního potenciálu spojeného s přirozeností lidské habituality.

\section{Masarykův reformismus kontra marxismus}

V sociologické praxi Masaryk upřednostňoval rovný přístup k pracovním př́ležitostem v tom smyslu, aby se jednotlivec mohl svobodně vzdělávat a pracovně se rozvíjet - takř́íkajíc nabývat štěstí. V podobném socializačním duchu tento nutný emancipační proces promýšleli také někteří další pozitivisticky zaměření myslitelé jak v Evropě, tak v obou Amerikách nebo Asii. A celkem úspěšně. Vznikají kupříkladu různé pozitivistické spolky pro dělnictvo a ke konci 19. století měly tyto pozitivistické tendence i aktivní vliv na řešení otázky otroctví. Ostatně sám Masaryk (podobně jako Anton 
Nyström ve Švédsku), spolu s tehdejší vůdčí osobností sociální demokracie Josefem Steinerem, zakládá v roce 1896 Dělnickou akademii, vlastně nejstarší think tank v Čechách (Rádl 1999, 443-444). Nicméně představa jakéhosi velekněze kultu lidství, do níž se v období tzv. druhé kariéry vyprofiloval Auguste Comte, byla Masarykovi cizí.

Všechny sklony zavánějící absolutní mocí striktně odmítal. Masarykovi šlo o emancipační úsilí ve smyslu demokratizace stávající společnosti, do vypuknutí světové války v podstatě o postupnou demokratizaci rakouské federace. Řešení sociální otázky viděl v celé škále postupných společenských reforem, ruku v ruce s pozitivním vzděláváním a mravní výchovou dělnictva. Jeho reformní úsilí tedy nesměřovalo k myšlence demontáže či snad zrušení státu, ale primárně ani ke změně vlastnických vztahů. Proto právě „metodickou“ otázku Jak pracovat? Masaryk považoval za „otázku všech otázek“. Uvědomělá práce podle Masaryka nepřetváří jen empirický svět. Je především duchovním úsilím, a tedy prostředkem vnitřní proměny člověka, který nevratně pochopil, jak Masaryk říká: svůj „poslední“ účel, jímž je vskutku trvalé uskutečňování ideálů lidskosti (Masaryk 1926, 26-28).

Onen duchovní či spirituální rozměr Masarykova myšlení, z něhož jeho normativní etika v principu vyvěrala, měl pak své nutné konsekvence v rovině filosofické. I když se Masaryk o Marxe zajímal už za svého pobytu ve Vídni a Lipsku, teprve až v Otázce sociální podrobuje vlastní filosofické a sociologické „základy“ marxismu důsledné kritice. Masaryk jaksi tradičně odmítal Hegelovu dialektiku, jež svým „revolučním“ charakterem aspirovala - a to navzdory ostrým kritikám v době jejího vzniku - být novou a progresivnější koncepční alternativou k tzv. evolučnímu historismu (Marcuse 1957). V tom se Masaryk podobal jak Bolzanovi, tak Brentanovi. Oproti vědeckému př́istupu a vědeckosti vůbec (Tvrdý 1932) ji považoval za jakousi neoprávněnou idealistickou substrukci či heuristickou ekvilibristiku - za „tajemný krám idealistické scholastiky“, jak říkal. A z pozice marxismu navíc zcela neoprávněnou, protože se z noetického hlediska vlastně stává dialektikou doslova „naruby“. Byl v zásadě toho názoru, že Marx chce Hegelovu dialektiku aplikovat na svou materialisticko-objektivistickou metodu, a to právě bez odkazu na jakoukoliv asubjektivní (v kantovském smyslu pak transcendentální) skutečnost, v níž musí být každé poznání a priori založeno. Marx a Engels podle Masaryka přijali metodu metafyzické a noetické soustavy naprosto cizí a sobě protivné, a tudíž je materialistická dialektika conradictio in adiecto (Masaryk 2000b, 54-59).

Hlavním důsledkem tohoto noetického rozporu, který v podstatě vylučuje každou možnost se principiálně vztahovat k naší prožívané skutečnosti, je pak tradiční pozitivistická teze, že hybné historické síly jsou 
ve skutečnosti nezávislé na ryze lidském, tedy psychologickém uvědomění. To je také důvodem, proč Marxův materialismus Masaryk nazývá pozitivismem či dokonce „ultrapozitivismem“ (Masaryk 2000b, 70). I to nejempiričtější vědecké a filosofické porozumění smyslovému světu podle Masaryka znamená umět jej „vyložit“, což však nutně předpokládá porozumění jeho smyslové „souvislosti“ - jinak je „iluzionismem“. Jeho slovy: „Smysl života a světa nelze vidět, nelze fotografovat, nýbrž jen vyložit tj. věčně hledat" (Masaryk 2000b, 144). Masaryk mimo jiné Marxovi vytýká nedostatečný smysl pro plnost života, že s city nechce mít nic společného, že jeho materialismus je humanitou „bez lásky“ a je tudíž oním „amoralismem“ (Masaryk 2000c, 148-152).

Jak se tedy ukazuje, jakási syntéza Masarykova realismu s Marxovým materialismem je neuskutečnitelná bez onoho primárního důrazu, jehož východiskem je svobodný a odpovědný, a tudíž aktivně fungující mravní subjekt. Každý odklon od tohoto principiálního východiska je neslučitelný $\mathrm{s}$ existenciálně motivovaným postojem, který je úhelným kamenem Masarykovy antropologie. I když ze sociologického hlediska Masaryk neupírá marxismu jeho pozitivní motivaci a emancipační potenciál, v podstatě marxismus chápe jako krizový jev. V tom spočívá Masarykova kritická argumentace proti revolučně pojímanému marxismu, ale také podstata pozitivní kritiky jeho dalších vývojových podob, jako právě tzv. „austromarxismu“, který u nás teoreticky propagoval Bohumír Šmeral. Masaryk ve Světové revoluci ostatně připomíná, že sám Šmeral na poradě Internacionály v roce 1917 nezakrýval, že drtivá většina dělnictva je pro samostatný český stát $\mathrm{v}$ rámci federativního Rakousko-Uherska a že tedy dělnictvu nejde o autonomii kulturní ve smyslu austromarxismu (Masaryk 2005, 169). A není právě v tomto kontextu nezajímavé připomenout, že vlastně sám Marx kriticky předjímal ony specifické podoby státoprávních tendencí vedoucích $\mathrm{k}$ dalšímu možnému politickému osamostatňování a sebeurčování národů $\mathrm{v}$ rámci monarchie. Tento vývojový trend potvrdily výsledky Slovanského sjezdu a staly se pak jedním z určujících faktorů Marxova negativního hodnocení historického vývoje v Čechách v roce 1848. A lze říci, že tyto jen partikulární státoprávní tendence Marx považoval - z hlediska svého universalistického pojímání dějin - za protirevoluční. To bylo také důvodem, proč Čechy tehdy neviděl zrovna v příznivém světle a spolu s Engelsem kritizoval kontrarevolučnost a panslavismus v postojích rakouských Slovanů. 


\section{Josef Ludvík Fischer: strukturální demokracie jako alternativa socialismu}

Za jistou alternativu či originální ideový pokus o doplnění marxismu ve smyslu kritiky vládnoucí podoby kapitalistického řádu a buržoazní demokracie vůbec lze na prahu třicátých let 20. století považovat Fischerovo pojetí strukturální filosofie. Přes zjevné počáteční sympatie k ruské bolševické revoluci a obhajobu sovětského společenského modelu, se však Fischer myšlenkově neztotožňoval s marxistickým, resp. marxisticko-leninským myšlením. I když marxismus vnímal jako vyjádření dobové emancipační touhy po novém společenském řádu, $v$ zásadě tento myšlenkový proud považoval za variantu filosofického naturalismu, čili za pouhou zvláštní „aplikaci př́rodovědeckého mechanismu na sociální dění. Marxismus podle Fischera překonává kapitalismus jen „protilogickým předpokladem vývojové dialektiky“ a je tudíž „folie kapitalismu, jen na ruby obrácená“. Chce tedy kapitalismus překonat pouze tím, „že jej neguje jeho vlastními zbraněmi, konkrétně tak, že kapitálovou ,hmotu' neguje sociální ,hmotou' = ,proletariátem'. Než negace kvantity kvantitou dovádí opět ke kvantitě a nikoli k (nové) kvalitě. Přijmeme-li kvantitativní princip za svůj, stává se jakýkoli dialektický proces logickou nemožností. Na tomto základním poznatku ztroskotává marxismus a celý socialismus, pokud vyšel z marxismu, s ním“ (Fischer 2007, 710) (Fischer 2005, 194).

Př́klon k tomuto novodobému (karteziánskému) prototypu obecně, $\mathrm{k}$ jeho mechanistickému determinismu a neosobnímu objektivismu - založenému na principu mechanistické kauzality - z něhož ostatně kapitalismus a s ním spojené „kvantitativně“ orientované pojetí demokracie vychází, je podle Fischera onou pravou př́činou hluboké stávající krize, která zasáhla všechny oblasti společenského dění. Inspirován především tvarovou psychologií a Diltheyovou kritikou experimentální přírodovědecké psychologie, ale i díky kritickému, avšak vnímavě otevřenému postoji k dobovým biologizujícím koncepcím dochází (v souvislosti s jeho novou interpretací Comta) k významnému sociologickému zjištění, „že totiž dosavadní vrcholný metodologický princip vědecké práce, žádající si výklad složitějších útvarů jednoduššími, respektive nižšími, bude nahrazen principem právě opačným, který by v útvarech nejsložitějších spatřoval klíč k výkladu všech skutečnostních útvarů ostatních“ (Fischer 2007, 400). Redukcionismus mechanistických koncepcí tak nahrazuje celostním jednotícím principem, což pak má (v dalších nutných sociologických souvislostech) svůj významný metodologický dopad na Fischerovo pojetí sociálního konsenzu. 
Tento klíčový pojem sociologické statiky, Fischer chápe jako funkční „jednotu struktury“. Jako ona (názorová) jednomyslnost podle něho proniká „Všechny sociální složky strukturálně totožnými principy“, jež pak „vtiskuji“" každé jednotlivé historické epoše její „specifický ráz“ - její typický (osmyslující) společenský „výraz“. Proto také může Fischer v konečném úhrnu tvrdit, že „moderní přírodověda, kapitalismus, demokracie, (marxistický) socialismus vykazují společné znaky“ toho, co nazývá „novodobým evropským kulturním prototypem“, resp. „mechanistickým prototypem“ jakožto „výrazem“ pro sociální konsensus zmírající epochy současnosti, jenž musí být následně pozitivně překonán „výrazem“ pro sociální konsensus kvalitativně a ireverzibilně vyšším. Sociální konsensus je tedy víc než pouhou „interakcí jednotlivých složek“, a už vůbec nejsou tyto dílčí složky jednostranně (abstraktivně) závislé na jedné jediné (Fischer 2013, 209). Fischer podnětně využívá své zevrubné studium Comtovy pozitivistické metody a v duchu její vědeckosti poukazuje na jistou metodologickou zvláštnost, která nám má umožnit názorně proniknout do samé filosofické podstaty jeho vlastního, strukturalisticky chápaného pojetí sociálního konsenzu.

Na pozadí těchto svých tvůrčích a kriticky vedených analýz nás Fischer upozorňuje, že v oblasti anorganických věd je „solidarita“ jednotlivých částí méně zjevná, nebot’ jednotlivé části jsou př́istupnější, než jejich celek a je tedy třeba vždy postupovat od jednoduššího ke složitějšímu. Právě ale v organické oblasti, jejímž hlavním předmětem je člověk a společnost, postupujeme zcela opačně - celek je nám lépe znám, než jeho jednotlivé části, které jsou k tomuto celku v určitém vztahu (Fischer 2007, 291). (Např. lidskému tělu lze jako celku porozumět jen na pozadí funkcí jeho jednotlivých tělesných orgánů.)

Ač v konkrétním sociologickém smyslu aplikačně složitější, nicméně v podstatě zcela totožný funkční princip pak musí platit i pro společnost, jejímž nejvlastnějším úběžným cílem je právě idea humanity. Z hlediska představy, že celek je (účelově) spínán funkcemi jeho částí, tj. pokud učiníme tento nutný krok a včleníme jej v tomto působivém relacionálním smyslu do funkční dynamiky skutečnosti, stává se podle Fischera zřejmé, že předěl mezi sociální statikou a dynamikou se „stírá“, a tudíž už nelze sociální konsenzus vnímat jako něco hotového: je invariantně vytvářen jako "dočasná výslednice" rozmanitých společenských tenzí. Pro sociologii se otevírá kýžený akční prostor jejího dalšího pozitivního „trvalého rozvoje“ a sociální dynamika se tím stává „nejzajímavější“ částí Comtovy sociologie (Fischer 2007, 292-293). A Fischer uzavírá: „Skutečnost ve strukturalismu jest řádovou skladbou jednotlivých částic, hierarchicky vršených a totalitně [rozuměj: celostně - J. S.] utvářených, schopnou trvalého vzrůstu 
(vývoje). - Pojem ,smyslu' dění nabývá v ní svého oprávnění, pokud jen vůbec dovedeme jednotlivé útvary a vrstvy skutečnostní hierarchie vykládati jako smysluplné. Kde není této možnosti, nutno se spokojiti s pouze formálním vyjádřením skutečnosti (anorganické), aniž by i zde přestávalo podřízení části celku“ (Fischer 2007, 711).

V ekonomickém ohledu má strukturalismus splňovat všechny požadavky kladené na tzv. socialismus (Fischer 2007, 711). Dostojí-li tedy Fischerův „ekonomický strukturalismus“ (jakožto nutná pozitivní skladebná součást kladoucí celostní důraz na hospodářský charakter společnosti) všech principiálních požadavků, představuje pak jakýsi specifický model socialistického systému v samé podstatě filosoficky nově založený - tudíž kvantifikujícímu způsobu novodobého myšlení se principiálně vymykající surogát marxismu - jenž svým „sociálním výrazem“ vychází z kvalitativních principů strukturální demokracie. I když má představovat demokracii kvalitativně nového vývojového typu, svou účinnou dynamickou povahou celostní skladby neodhlíží od potřeby plurality svobodných a harmonicky rozvinutých jednotlivců. Jejich svoboda, tedy i volba možností jsou však vždy primárně podmíněny „svobodou v řádu“ skladebného sytému, v nichž jednotlivé části plní určité funkce. A jelikož právě neodmyslitelnou tvůrčí částí tohoto sytému je i člověk, musí se tento ontologický princip vztahovat i na všechny jednotlivé subjekty. „Sociální rovnocennost“ těchto individuí proto Fischer primárně odvozuje z jejich „sociálních funkcí" jakožto základních ontologických jednotek určujících vztahy mezi těmito „uvědomujícími se“ subjekty. A Fischer upřesňuje: „Sociální řád ve strukturální demokracii vzniká skladbou částečných sociálních funkcí, jejichž nositeli jsou jednotlivé subjekty, tato skladba pak podléhá veskrzné jejich kontrole" (Fischer 2007, 711).

Výchozí teze Fischer stručně, ale komplexně shrnul v únoru 1930 v svém, mohli bychom bez nadsázky říci - manifestu strukturalismu, který pod výstižným názvem $O$ dvojím řádu zveřejnil v České mysli, a dále je ve smyslu skladebné ontologie podnětně rozvíjel i v šedesátých letech. Jak ideologicky podnětné tyto Fischerovy teze byly v době tehdejších pokusů o revizi stávajícího socialistického systému a jak životaschopně vyhlížející se svým universalistickým charakterem jevily některým reformním filosofům, nám napoví následující hodnocení Josefa Zumra z konce šedesátých let: „Význam těchto tezí spočívá v tom, že se tu poprvé v českém kulturním kontextu formuluje problém strukturalismu nejen jako problém metodologický, noetický a ontologický, ale přímo jako otázka světonázorová, jako nástin ideologie socialistické levice. Tím zároveň význam těchto tezí překračuje hranice české kultury a stává se problémem evropským" (Zumr 1969, 75). 


\section{Fischer a Masaryk}

I když se už z výše naznačených skutečností potřebnou měrou ozřejmilo, že se jedná o problematiku komplexní a v mnoha ohledech (především v souvislosti s dalšími příbuznými dobovými myšlenkovými proudy) nerozpracovanou, nelze si už na tomto místě nepovšimnout, že Fischerova strukturálně-filosofická východiska jsou odlišné povahy něž principiální filosofická východiska Masarykova. Připomínáme tuto skutečnost, protože je stejně tak dobře známo, že J. L. Fischer měl nutkavou potřebu se Masarykem zevrubně zabývat a kriticky ho promýšlet celý svůj život (jak lze dohledat v třetím svazku jeho Výboru z díla). Stejně jako Masaryk byl především nesmlouvavým kritikem své doby a př́značné podoby jejího demokratického směřování. Na konci 19. století a koncem dvacátých let 20. století ovšem demokracie vykazovala ve svých vývojově-historických fázích různé krizové jevy, na jejichž typiku bylo třeba klást potřebný kritický důraz.

Vyjdeme-li však od této obecné charakteristiky směrem k jejímu konkrétnímu filosofickému řešení, můžeme povýtce konstatovat, že kromě Masarykova aktivistického pojetí „drobné práce“ pro společnost, které ve své rané myšlenkové fázi Fischer zprvu nacházel v revolučně pojatém a voluntaristicky směřovaném pragmatismu (ostatně vlastně obdobně jako např. Karel Čapek) , lze jak Masaryka, tak Fischera považovat za myslitele krize. Její důvody oba tito naši myslitelé objektivně opírali o vědecky zdůvodněné a sociologicky fundované argumenty, nicméně jejich principiální filosofická východiska byla diametrálně odlišná. Krizi, kterou koncem dvacátých a počátkem třicátých let ve společnosti Fischer identifikoval, obecně vnímal jako krizi strukturální, resp. jako krizi fungování stávajících demokratických struktur, nikoli jako krizi moderního a citově neukotveného člověka-jednotlivce. Lék na překonání této krize tedy nehledal v individualistickém „antropologismu“ v Masarykově smyslu, ale právě v cílené filosoficko-sociologické analýze těchto stávajících disfunkčních, k „patologii" tíhnoucích demokratických struktur jako celku a potažmo pak v hledání strukturálních možností jejich systémové resuscitace. V tomto zásadním strukturálním vědeckém ohledu (nevylučujícím předvídání potenciálních negativních společenských jevů), už ale nelze přímo hovořit o emancipaci národní, ale vlastně o emancipaci státně-systémové, jíž nelze upřít univerzalistický ráz. Tyto univerzální a proměnlivě dynamické původní struktury pak představují kýžené (asubjektivní) funkční rámce srozumitelnosti jakožto možnosti naší (subjektivní) orientace (Svoboda 2017, 39-42). 
Odhalení funkčnosti těchto principiálních dynamických struktur však předcházelo intenzivní tvůrčí období, kdy se Fischer jako mladý a levicově orientovaný intelektuál vyrovnával s negativní zkušeností první světové války. Nové generaci mladých intelektuálů se doslova zbortil svět a nebylo v silách tehdy vládnoucího objektivistického pozitivismu (jehož koryfejem u nás byl František Krejčí a jehož žákem ostatně byl i J. L. Fischer) nabídnout pozitivní řešení. Právě v posledních válečných letech a prvních letech poválečných Fischer nalézal východisko stávající neutěšené sociální situace $v$ revolučně interpretovaném pragmatismu. $V$ něm viděl potřebný a čerstvý tvůrčí náboj, který má schopnost svět proměňovat takř́íkajíc k obrazu svému a jako představitel nemarxistické levice právě v tomto filosofickém směru hledal možnost účinného naplnění své voluntaristické touhy k činu. Navíc byl Fischer přesvědčen, že oproti abstraktnímu pojímání pravdy a přemíře intelektualismu svým požadavkem přísné empiričnosti pragmatismus propůjčuje pojmu humanismus nový, praktický a lidský ráz. Otevíral tedy Fischerovi potřebnou možnost nově promýšlet otázky subjektu a subjektivity vůbec, a tedy i problematiku lidských práv atd., tj. být oním aktivním spolutvůrcem přetváření stávající hodnotové skutečnosti.

Výsledkem jeho počáteční usilovné filosofické práce se stal principiální přechod od voluntaristického pragmatismu k strukturalistické filosofii. Tento reduktivní ideový obrat by byl ale jen sotva možný bez pečlivého studia a zevrubného promýšlení především Augusta Comta, filosofa a klasika sociologie pro českou filosofickou i obecně intelektuální provenienci $\mathrm{v}$ té době už tradičně zavedeného a originálně kriticky rozvíjeného $\mathrm{v}$ dalších kontextech pozitivistického myšlení. A tedy i v tomto už tradičním receptivním ohledu lze Fischera považovat za jednoho z předních českých myslitelů, kteří byli schopni Masaryka nejen kriticky promýšlet, ale také originálně a v moderním duchu doby konsekventně domýšlet. Právě na Fischerovi se dobře v jistém směru potvrzuje Rádlova výzva pro budoucí filosofickou generaci: „Masaryk jako pionýr prosekává jen nejhlavnější cesty a starost o podrobnosti ponechává druhým: taková jest už metoda pionýrů“ (Rádl 1937, 444).

\section{Hrubého vize kontinuity českých dějin a globálně-humanitární výzvy}

Koncem devadesátých let 20. století se ve významné shodě s T. G. Masarykem a J. L. Fischerem nad krizí stávající podoby demokracie svým způsobem kriticky zamýšlí i Karel Hrubý. Pojetí „demokratického socialismu" důvodně očištuje od všech ideologických nánosů a rigidních teoretických definic, jež prvoplánově odvracejí pozornost od jeho funkční 
podstaty a negují tím potřebnou vůli a motivaci jednotlivce k činu. Varuje před nežádoucími ekvivokacemi pojmů „socialismus“ i „demokracie“, čímž otevřeně a bez nádechu jakéhokoli ideologizujícího obskurantismu vyjadřuje především svůj vlastní ideový postoj i sociálně orientované přesvědčení. Právě u pojmu „socialismus“ je podle Hrubého vždy třeba obezřetně rozlišovat, zda jde o koncepci socialismu „marxistické provenience (respektive jeho marxisticko-leninskou derivaci) či o socialismus vycházející z jiných ideových kořenů“. Nebo se jedná o „socialismus chápaný jako cílové stadium vývoje společnosti - anebo o socialismus, který se neupíná k určité ideologii ani k nějakému konečnému cíli či historicky ,nutně’ přicházejícímu systému, nýbrž k člověku ,zde a nyní, o jehož vyšší lidskou důstojnost a životní kvalitu mu jde především“ (Hrubý 1993-1994, 602). A k dnes už často důvodně zmiňovaným reformním pokusům z šedesátých let 20. století na obranu skutečně fungující „demokracie“ kriticky dodává: „To, co lidé ,beroucí teprve rozum' mohli roku 1968 považovat za uspokojivou demokracii, bylo pro většinu těžce zkoušeného národa pořád ještě citelným regresem proti zážitku demokracie let 1945-47, o demokracii první Československé republiky ani nemluvě“ (Hrubý, 1993-94, 602).

Následně pak vědomě a předjímavě vytyčuje některé stěžejní společenské problémy, které budou podle něho „rozhodovat o budoucím charakteru národa, a tím i o české otázce 21. století" (Hrubý 1997, 27). V prvé řadě před nás klade otázku: „Na čem je možno založit moderní ideu humanity, resp. jak je možné ono vnitřní obrození, ono patočkovské ,otevření tomu, co přesahuje člověka jako individuum i jako společnost?“ Hrubého odpověd, jež tedy nutně nepředpokládá náboženské zdůvodnění, zní: „Potřebujeme humanitu vpravdě univerzálního charakteru, která by mohla být sdílena všemi. Jde o nalezení takového konceptu humanity, v němž se všechny její proudy - masarykovský, kantovský, benthamovský aj., humanismus křestanských církví i humanismus atheistický - sejdou v základním konsenzu nejen kritérií Dobra a Zla, ale i v stanovení pravidel soužití majících závaznost pro všechny. Je třeba humanity proti nehumanitě, programu odpovědnosti proti lhostejnosti, programu slušnosti proti rabiátství, ale především je třeba respektu k obecně lidské podstatě a základním právům každého člověka" (Hrubý 1997, 28). A v osvícenském a nadčasově imperativním duchu ideálů humanity, ale i v úzké souvislosti s myšlenkou, jíž Masaryk nepokrytě vyjádřil ve Světové revoluci na úkor nutnosti uznání lidské individuality a potřeby jejího mravního (sebe)uvědomění, jednoznačně dodává: „Člověk člověku nesmí být jen prostředkem.... Proti budoucnosti, která hrozí být pouhou „bio-sociální existencí", Karel Hrubý staví reálný národní program, jehož předpokladem musí být 
účinná výchova k demokracii a odpovědnému občanství (Hrubý 1997, 28; Hrubý 2019, 23).

K těmto nadčasovým univerzálním výzvám, které mají ideově směřovat náš národní program, dnes už patří i takové naléhavé a stále se prohlubující výzvy globálního charakteru (Latour 2020, 22), jako jsou např. světová chudoba (v současnosti spojená s válkami a migrační krizí), intenzivní znečištování naší planety, ubývání zdrojů vody či hledání společných účinných a odpovědných řešení spojených s civilizační hrozbou pandemie COVID-19. Tyto celosvětové humanitární výzvy volají po reálné bázi lidské důvěry a vzájemného porozumění - po otevřeném interkulturním dialogu. Současně jsme svědky pronikání různých náboženských a duchovních alternativních proudů, které více či méně nastavují zrcadlo dnešní konzumní společnosti chvilkových prožitků. Tyto proudy v naší kultuře neodmyslitelně zakotvily a takříkajíc ji globálně spoluurčují. A má-li být vlastní podstatou moderní pozitivní politiky nábožensky orientovaná humanita jako záruka politické mravnosti, potřebujeme podle Masaryka náboženství nové, čerstvější (Masaryk 1947, 25; Tvrdý 1921, 128-129), které se bude opírat o racionální pozitivistickou vědu a vědeckost. I když Masarykovo náboženské východisko bylo ideově spjato s křestanskou reformací, zůstává právě v dnešní době otevřenou otázkou, zda jakýsi druh náboženského synkretismu není v budoucnosti oním kýženým morálněpolitickým předpokladem odpovědného řešení neodkladných problémů a výzev naší současnosti (Funda 2017, 26).

\section{Literatúra}

ČAPEK, K. (2013): Hovory s T. G. Masarykem. In: Opelík, J. (ed.): Spisy T. G. Masaryka, sv. 37. Praha: Ústav T. G. Masaryka, o. p. s. - Masarykův ústav a Archív AV ČR, v. v. i., $13-347$.

ČAPEK, K. (1925): Pragmatismus čili filosofie praktického života. Praha: Topič.

ČERNÝ, V. (1946): Boje a směry socialistické kultury. Praha: F. Borový.

FISCHER, J. L. (2005): Krise demokracie. Praha: Karolinum.

FISCHER, J. L. (1969): Skladebná filosofie, strukturalismus a dialektika. In: Filosofický časopis, 17 (1), 13 - 27.

FISCHER, J. L. (2007): Výbor z díla, I. Praha, Olomouc: Academia - Univerzita Palackého v Olomouci.

FISCHER, J. L. (2013): Výbor z díla, III. Olomouc: Univerzita Palackého v Olomouci. FUNDA, O. A. (2002): Rudolf Bultmann - demytologizace a existenciální interpretace zvěsti křest’anské víry. In: Filosofický časopis, 50 (4), 615 - 638.

FUNDA, O. A. (2017): K filosofii náboženství. Praha: Karolinum. 
GRIM FEINBERG, J. (2020): Emancipace mezi národem a humanitou: T. G. Masaryk a specifika česko-rakouské tradice: rozhovor Josepha Gima Feinberga s Janem Svobodou.In:Kontradikce.Časopisprokritickémyšlení,3(1),144-156.Web. 2020. <https://kramerius.lib.cas.cz/periodical/uuid:dbe7fa7f-e521-4d6a-8bfbb9f5c6e84ce2 >

HRUBÝ, K. (2019): Cesty komunistickou diktaturou. Kritické studie a eseje. Hermann. T. (ed.). Praha: Argo - Ústav pro soudobé dějiny AV ČR.

HRUBÝ (1993-1994), K.: Co je demokratický socialismus? In: Soudobé dějiny, 1 (4-5), $598-602$.

HRUBÝ, K. (1997): Karel Hrubý, Naše dnešní otázky. In: Broklová, E. (ed.): Sto let Masarykovy české otázky. Sborník př́spěvků z mezinárodní vědecké konference pořádané pod záštitou prezidenta republiky Masarykovým ústavem Akademie věd České republiky a Masarykovou univerzitou v Brně v součinnosti s Vojenskou akademií v Brně a Masarykovým muzeem v Hodoníně za podpory České pojištovny v Brně ve dnech 26.-28. záŕí 1995 v Brně. Praha: Ústav T. G. Masaryka, 27 - 33. HRUBÝ,K. (2005):SjezdČSSDv duchu Godesbergu, aneboledna 1968? In:Listy,35(1), 8 - 9. Web. <http://www.listy.cz/archiv.php?cislo=051\&clanek=010502>.

KOMENSKÝ, J. A. (1992): Obecná porada o nápravě věcí lidských. Praha: Svoboda. LATOUR, B. (2020): Zpátky na zem. Praha: Neklid.

LOCHMAN, J. M. (1998): Masarykův zápas s Marxismem v teologické perspektivě. In: Sociologický časopis, 34 (4), 427 - 436.

MALIŇÁKOVÁ, K. - TRNKA, R. - ŠÁRNÍKOVÁ G. - SMÉKAL, V. - FÜRSTOVÁ, J. TAVEL, P. (2018): Psychometrická analýza škály každodenní spirituální zkušenosti (DSES) v českém prostředí. In: Československá psychologie, vLXII (Supplement 1), 2-18. Web. 1. Mar. 2019. <http://cspsych.psu.cas.cz/files/ cspsych_supplement_2018.pdf>.

MARCUSE, H. (1957): Reason and Revolution. London-New York-Toronto: Oxford University Press, 1941. Částečně česky v překladu R. Hrbkové: Základy positivismu a vznik sociologie. Positivní a negativní filosofie (k 100. výročí A. Comta). In: Filosofický časopis, 5 (6), 902 - 915.

MASARYK, T. G. (2000a): Česká otázka. Naše nynější krize. Jan Hus. In: Brabec, J. (ed.): Spisy T. G. Masaryka, sv. 6. Praha: Masarykův ústav AV ČR - Ústav T. G. Masaryka, 11 - 492.

MASARYK, T. G. (1946): Ideály humanitní. Praha: Čin.

MASARYK, T. G. (1929): Jak pracovat. Praha: Čin.

MASARYK, T. G. (1902): Ke klasifikaci věd (Ethika - filosofie - theologie). In: Česká mysl, $3(6), 1-2$.

MASARYK, T. G.(2016): Nová Evropa. Stanovisko slovanské. In: Kessler, V. (ed.): Spisy T. G. Masaryka, sv. 14. Praha: Ústav T. G. Masaryka, o.p.s. - Masarykův ústav a Archiv AV ČR, v.v.i., 11-255.

MASARYK, T. G. (1990): O bolševictví. Praha: Evropský kulturní kruh.

MASARYK, T. G. (2000b): Otázka sociální, I. In: Srovnal, J. (ed.): Spisy T. G. Masaryka, sv. 9. Praha: Masarykův ústav AV ČR - Ústav T. G. Masaryka, 9-283.

MASARYK, T. G. (2000c): Otázka sociální, II. In: Srovnal, J. (ed.): Spisy T. G. Masaryka, sv. 10. Praha: Masarykův ústav AV ČR - Ústav T. G. Masaryka, 11-299. 
MASARYK, T. G. (2001a): Pokus o konkrétní logiku. In: Srovnal, J. (ed.): Spisy T. G. Masaryka, sv. 3. Praha: Masarykův ústav AV ČR a Ústav T. G. Masaryka, $9-261$.

MASARYK, T. G. (1998): Přednášky a studie z let 1882-1884. In: Polák, S. - Brabec, J. (eds.): Spisy T. G. Masaryka, sv. 17. Praha: Ústav T. G. Masaryka, $11-182$.

MASARYK, T. G. (1900): Rukovět' sociologie. Podstata a metoda sociologie. In: Naše doba, 8, (1), $1-12$.

MASARYK, T. G. (1995): Rusko a Evropa, I. In: Franěk, J. a kol. (eds.): Spisy T. G. Masaryka, sv. 11. Praha: Ústav T. G. Masaryka, 9 - 394.

MASARYK, T. G. (1996): Rusko a Evropa, II. In: Pochman, J. - Svatoň, V. (eds.): Spisy T. G. Masaryka, sv. 12. Praha: Ústav T. G. Masaryka, $11-495$.

MASARYK, T. G. (1998): Sebevražda hromadným jevem společenským moderní osvěty. In: Srovnal, J. (ed.): Spisy T. G. Masaryka, sv. 1. Praha: Ústav T. G. Masaryka, $9-221$.

MASARYK, T. G. (2005): Světová revoluce. Za války a ve válce 1914-1918. In: Srovnal, J. (ed.): Spisy T. G. Masaryka, sv. 15. Praha: Masarykův ústav AV ČR T. G. Masaryka, o. p. s., 9 - 639.

MASARYK, T. G. (2012): Univerzitní přednášky I. Praktická filozofie. In: Gabriel, J. a kol. (eds.): Spisy T. G. Masaryka, sv. 4. Praha: Ústav T. G. Masaryka, o. p. s. Masarykův ústav, $11-471$.

MASARYK, T. G. (1947): V boji o náboženství. Praha: Čin.

MASARYK, T. G. (2001b): Základové konkretné logiky. In: Olšovký, J. - Srovnal, J. eds.): Spisy T. G. Masaryka, sv. 2. (eds.). Praha: Masarykův ústav AV ČR - Ústav T. G. Masaryka, 9 - 205.

NOVÝ, L. (1994): Filosof T. G. Masaryk. Problémové skici. Brno: Doplněk.

RÁDL, E. (1999): Dějiny filosofie II. Novověk. Praha: Votobia.

RÁDL, E. (1937): T. G. Masaryk. In: Durant, W: Od Platona $k$ dnešku. Vývoj filosofie v jejích velkých představitelích. Praha: Sfinx Bohumila Jandy, $434-475$.

Ř́lČAN, P. (2002): Psychologie náboženství. Praha: Portál.

ŘíČAN, P. (2007): Rozhovor: Psycholog Pavel Říčan - Nejdůležitější je autenticita. In: Psychologie náboženství a spirituality. Praha: Portál. Web. 18. Jan. 2019. <https://nakladatelstvi.portal.cz/nakladatelstvi/aktuality/98632/ nejdulezitejsi-je-autenticita-rozhovor-s-pavlem-ricanem>.

SVOBODA, J. (2009): Masaryk a Kant: vliv Brentanovy kritiky, souvislost s Masarykovou reakcí na mysticismus v ruském myšlení. In: Filosofický časopis, 57(4), $523-553$.

SVOBODA, J. (2018): Moderna a transcendence ve světle Masarykova realismu. In: Filosofický časopis, 2018, 66 (5), 679 - 697.

SVOBODA, J. (2019): Platónské východisko Palackého pojmu 'božnost'. In M. Bednář (ed.), Idea dějin a Palacký jako myslitel. Soubor textů. Praha: Filosofia, 97-104.

SVOBODA, J. (2017): Whiteheadova interpretace Platónovy „schránky“ a paralely s pojmem "nadčasové skutečnosti“. In: Studia philosophica, 64 (2), 21 - 42. Web. 2017. < https://digilib.phil.muni.cz/handle/11222.digilib/137299>. 
ŠAMALÍK, F. (2006): Zdroje sociálnědemokratického hnutí. In: Hrubec, M. Bárta, M. (eds.): Dějiny českého a československého sociálnědemokratického hnutí. Praha - Brno: Masarykova dělnická akademie - nakladatelství Doplněk, $13-35$.

ŠOLCOVÁ, K. (2017): Karafiátova odpověd' na „Českou otázku“. In: Svoboda, J. Prázný, A. (eds.): Česká otázka a dnešní doba. Praha: Filosofia, 537 - 551. TVRDÝ, J. (1921): Filosofie náboženství. Brno: Osvětové knihkupectví J. Kajše.

TVRDÝ, J. (1932): Nová filosofie. Analysa dnešní filosofické situace. Praha: Volné myšlenky.

ZOUHAR, J. - PAVLINCOVÁ, H. - GABRIEL, J. (2013): Česká filosofie v letech 1945 1948. Praha: Academicus.

ZUMR, J. (1969): Vývoj českého strukturálního myšlení do roku 1930. In: Filosofický časopis, 17(1), 67 - 75.

PhDr. Ing. Jan Svoboda, M.A., Ph.D.

Filosofický ústav AV ČR, v.v.i.

Jilská 1, Praha 1, 11000

svobodaj@flu.cas.cz 